\title{
Carotenoid Content and In Vitro Bioaccessibility of Lutein in Some Leafy Vegetables Popular in Sri Lanka
}

\author{
Udumalagala Gamage CHANDRIKA ${ }^{1}$, \\ Basnayake Mudiyanselage Lohitha Bandara BASNAYAKE ${ }^{2}$, Indika ATHUKORALA ${ }^{1}$, \\ Pula Wahampurage Nilanka Madurangi ColOMBAGAMA ${ }^{3}$ and Anil GoonETILLEKE ${ }^{2}$ \\ ${ }^{1}$ Department of Biochemistry, Faculty of Medical Sciences, ${ }^{2}$ Department of Pharmacology, Faculty of Medical \\ Sciences, and ${ }^{3}$ Department of Food and Science and Technology, University of Sri Jayewardenepura, \\ Gangodawila, Nugegoda, Sri Lanka \\ (Received December 4, 2009)
}

\begin{abstract}
Summary Lutein is one of the major carotenoids in green leafy vegetables (GLVs), which show a marked antioxidant activity. The study was carried out to identify and quantify the carotenoid content of selected Sri Lankan GLVs. RP-HPLC with photodiode array detection method was followed for the separation, identification and quantification of carotenoids. Among the vegetables analyzed, Ipomoea batatas leaves showed the highest $\beta$-carotene content $(743.9 \pm 35.0 \mu \mathrm{g} / \mathrm{g}$ dry weight (DW)) while Syngonium angustatum leaves contained the highest amount of lutein $(1,728.2 \pm 168.3 \mu \mathrm{g} / \mathrm{g} D W)$. Percentage in vitro bioaccessibility of lutein from cooked GLVs ranged from 10.1 to $48.0 \%$ in stir-fried preparations of Centella asiatica and Cucurbita maxima, respectively. Hence these GLVs can be exploited as a rich source of $\beta$-carotene and lutein to overcome vitamin A deficiency and age-related macular degeneration.
\end{abstract}

Key Words $\beta$-carotene, lutein, HPLC-DAD, green leafy vegetables, in vitro bioaccessibility

Lutein is one of the major carotenoids in green leafy vegetables (GLVs), which show a marked antioxidant activity. It is a predominant carotenoid of human macular pigment and it is known to protect the eye by giving protection against age-related macular degeneration (AMD) by preventing light-initiated oxidative damage to the retina, mediated by its ability to quench singlet oxygen and blue light in the retina (1). Previous studies using humans suggested that the bioavailability of the more hydrophilic lutein from vegetables is 5 times higher than that of $\beta$-carotene (2). The content of lutein of even the most widely consumed Sri Lankan GLVs has not been reported. Also no reliable information is available on the relative bioaccessibility of lutein from GLVs. Therefore the content and in vitro accessibility of lutein from Sri Lankan cooked GLVs was studied.

Lutein is the second most prevalent carotenoid in human serum (3) and is abundantly present in dark GLVs such as Spinacea oleracea (4). Not only important for eye health, consumption and serum levels of lutein have been shown to be inversely related to the risk of $\operatorname{AMD}(5,6)$ and cataracts $(7-9)$. Recent findings suggest that ingestion of lutein-containing food or supplements results in increased macular pigment optical density $(10,11)$ and may help to improve visual function in patients suffering from AMD and other ocular diseases (12).

Several studies suggest that lutein and zeaxanthin, a

E-mail: udumalagala2002@yahoo.com stereoisomer of lutein, may help maintain the condition of the heart by reducing the risk of atherosclerosis (13, 14). The objective of the present study was (i) to identify and quantify the main carotenoids of thirteen GLVs popular in Sri Lanka and (ii) to determine the in vitro bioaccessibility of lutein in selected heat processed GLVs with high lutein content.

\section{Materials and Methods}

Sampling. Thirteen types of fresh green leafy vegetable samples (4 samples from each type) were collected from different points in and around Colombo district, Sri Lanka. They consisted of Gymnema lactiferum (Kurignan), Polyscias scutellaria (Koppa kola), Syngonium angustatum (Wel kohila), Boerhavia diffusa (Pitasudu sarana), Triathema monogyna (Sarana), Manihot esculenta (manioc), Cucurbita maxima (Pumpkin leaves), Ipomoea batatas (Sweet potato leaves), Spinaces oleracea (Nivithi), Amaranthus caudatus (Thampala), Sesbania grandiflora (Katurumurunga), Alternathera sessilis (Mukunuwanna) and Centella asiatica (Gotukola). These plants were taxonomically identified by a botanist (Dr. P. Mahagamasekara) and voucher specimens were deposited in the Botany Laboratory, University of Sri Jayewardenepura for future reference.

RP-HPLC-DAD analysis of carotenoids. Quantification was performed using high performance liquid chromatography with Diode Array Detection (HPLC-DAD), using HPLC series 1200 (Agilent, Germany) equipped with Chem-Station software, a degasser G 13322 A, quaternary gradient pump G1311A, an auto sampler G 


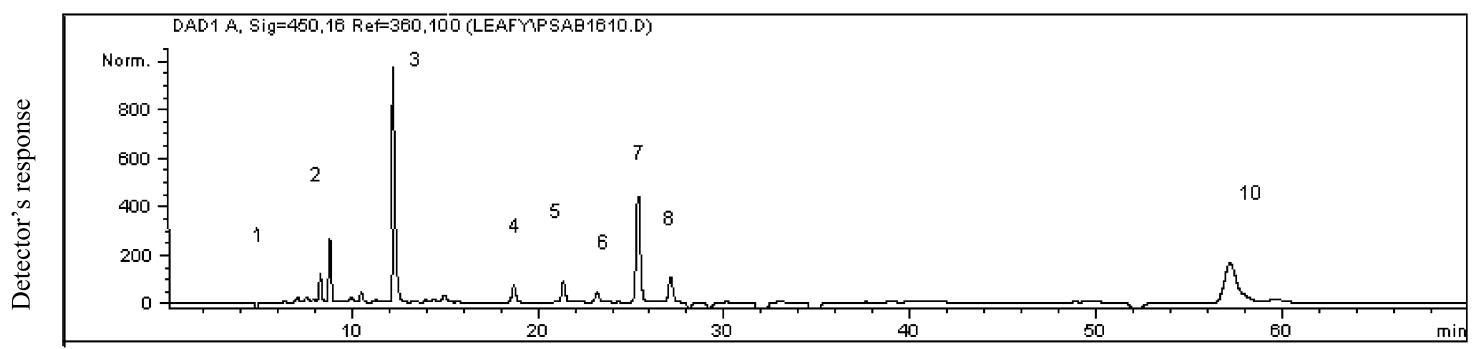

(a)

Time (min)

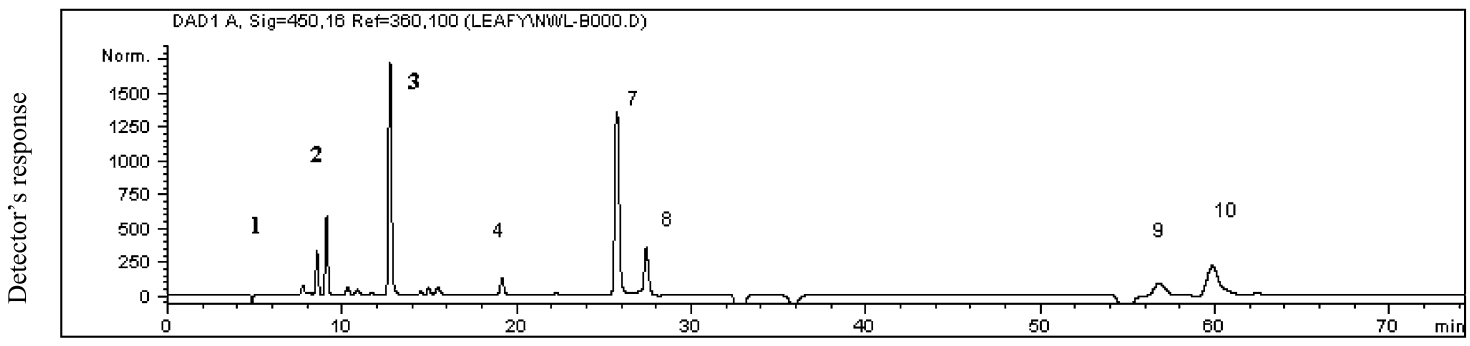

(b)

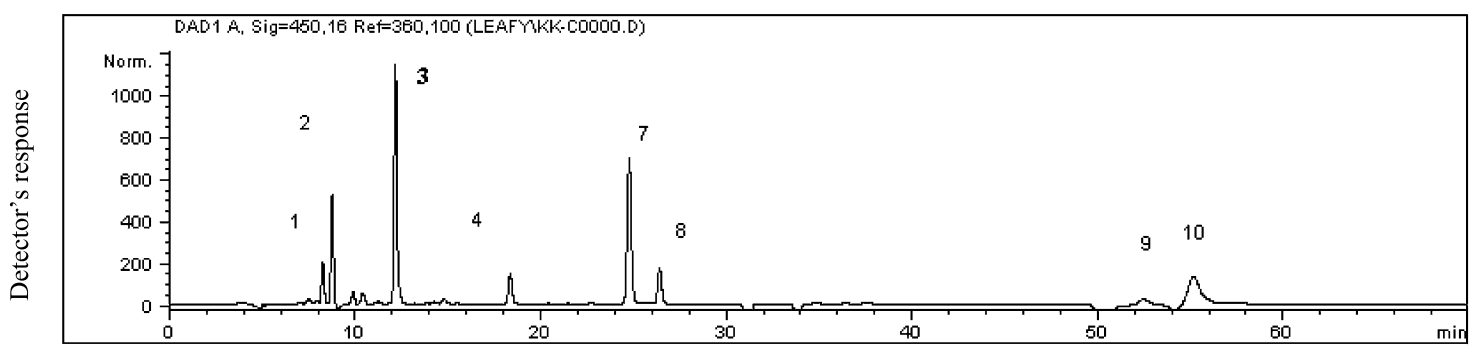

(c)

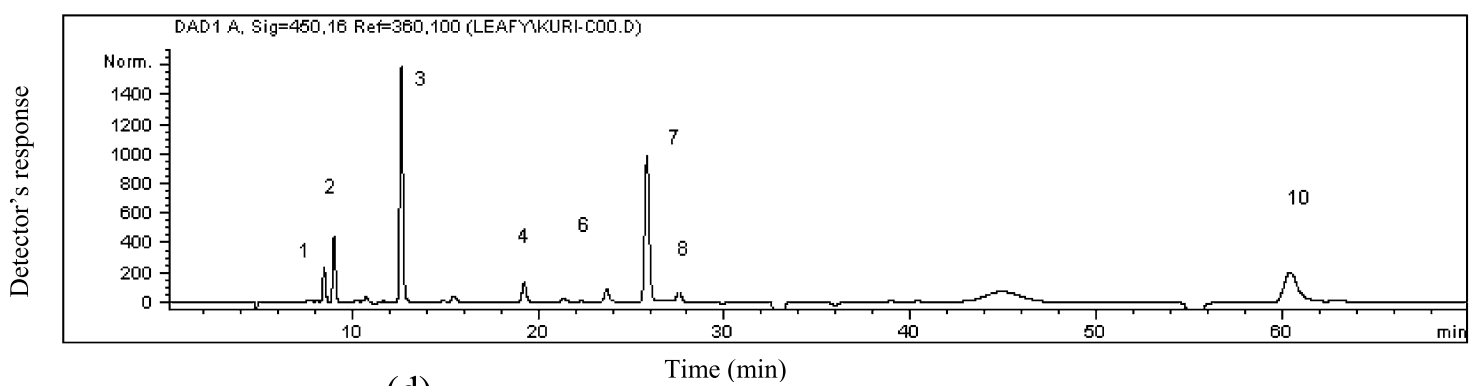

(d)

Fig. 1. RP-HPLC chromatograms of the carotenoids of (a) Boerhavia diffusa, (b) Syngonium angustatum, (c) Polyscias scutellaria, (d) Gymnema lactiferum. Peak identification: 1 , neoxanthin; 2 , violaxanthin; 3, lutein; 4 , $\beta$-cryptoxanthin; $5, \alpha$-cryptoxanthin; $6, \beta$-carotene 5,6,5',6' diepoxide; 7, $\beta$-apo-8' carotenal (internal standard); 8 , chlorophyll peak; $9, \alpha$-carotene; $10, \beta$-carotene.

1329 A, a column oven G 1316 A and a diode array detector G1315B. The mobile phase consisted of acetonitrile, methanol and ethyl acetate containing $0.05 \%$ of triethylamine used at a flow rate of $0.5 \mathrm{~mL} / \mathrm{min}$ with diode array detection, using a monomeric $\mathrm{C}_{18}$ column (Agilent), $3 \mu \mathrm{m}, 4.6 \times 250 \mathrm{~mm}$. A gradient was applied from $95: 05: 00$ to $60: 20: 20$ in 70 min maintaining this proportion until the end of the run. Purity of the peaks was confirmed using a UV visible photodiode array detector. Quantification of carotenoids was done using external standardization. The internal standard used was $\beta$-apo- 8 'carotenal.

Isolation of neoxanthin and violaxanthin standards was performed with open column chromatography (OCC) using Sesbania grandiflora leaves. $\beta$-Carotene and lutein standards were purchased from Sigma (USA).

Carotenoids for HPLC analysis were isolated as we have done in our previous studies (15). Identification of carotenoids was carried out according to the Rodriguez-Amaya (16).

Preparation of green leaves with scraped coconut. The preparation procedure of GLVs before cooking included washing the sorted leafy vegetables $(200 \mathrm{~g})$ after which the leaves were finely cut and mixed with scraped coconut $(200 \mathrm{~g})$. Cooking of leafy vegetables involved heating this mixture for $5-10 \mathrm{~min}$ in an uncovered pan 
Table 1. Carotenoid compositions of some raw green leafy vegetables popular in Sri Lanka.

\begin{tabular}{|c|c|c|c|c|c|}
\hline \multicolumn{2}{|c|}{ Green leafy vegetable } & \multirow{2}{*}{$\begin{array}{l}\beta \text {-Carotene } \\
(\mu \mathrm{g} / \mathrm{g} D W)\end{array}$} & \multirow{2}{*}{$\begin{array}{c}\text { Lutein } \\
(\mu \mathrm{g} / \mathrm{g} D W)\end{array}$} & \multirow{2}{*}{$\begin{array}{c}\text { Neoxanthin } \\
(\mu \mathrm{g} / \mathrm{g} D W)\end{array}$} & \multirow{2}{*}{$\begin{array}{c}\text { Violaxanthin } \\
(\mu \mathrm{g} / \mathrm{g} \mathrm{DW})\end{array}$} \\
\hline Botanical name & $\begin{array}{l}\text { Local name } \\
\text { (Sinhalese) }\end{array}$ & & & & \\
\hline Polyscias scutellaria & koppa kola & $165.5 \pm 32.1$ & $892.4 \pm 121.9$ & $77.6 \pm 12.5$ & $137.3 \pm 11.9$ \\
\hline Gymnema lactiferum & kurignan & $162.9 \pm 48.0$ & $928.9 \pm 174.9$ & $90.8 \pm 14.9$ & $162.5 \pm 26.4$ \\
\hline Syngonium angustatum & wel kohila & $263.4 \pm 42.5$ & $1,728.2 \pm 168.3$ & $109.9 \pm 32.5$ & $280.2 \pm 19.8$ \\
\hline Boerhavia diffusa & pitasudu sarana & $386.3 \pm 43.6$ & $1,472.6 \pm 205.9$ & $144.5 \pm 22.3$ & $273.3 \pm 17.2$ \\
\hline Manihot esculenta & manioc & $517.5 \pm 75.6$ & $1,655 \pm 23.4$ & $246.9 \pm 14.5$ & $439.2 \pm 25.6$ \\
\hline Triathema monogyna & sarana & $560.3 \pm 30.8$ & $760 \pm 20.7$ & $231.6 \pm 12.5$ & $579.8 \pm 20.0$ \\
\hline Spinaces oleracea & nivithi & $300.9 \pm 18.5$ & $640 \pm 18$ & $96.7 \pm 7.9$ & $241 \pm 13.9$ \\
\hline Amaranthus caudatus & thampala & $400.4 \pm 25.8$ & $490 \pm 19.5$ & $146.8 \pm 10.6$ & $333.2 \pm 22.7$ \\
\hline Cucurbita maxima & pumpkin leaves & $655.0 \pm 40.5$ & $1,534.4 \pm 48.2$ & $327.8 \pm 13.7$ & $818.5 \pm 28.0$ \\
\hline Ipomoea batatas & sweet potato leaves & $743.9 \pm 35.0$ & $1,685.8 \pm 101.7$ & $256.3 \pm 19.4$ & $640.4 \pm 30.5$ \\
\hline Sesbania grandiflora & katurumurunga & $402.4 \pm 31.1$ & $1,084.8 \pm 21.3$ & $321.8 \pm 13.2$ & $335.9 \pm 20.0$ \\
\hline Alternathera sessilis & mukunuwanna & $280.4 \pm 25.4$ & $295.5 \pm 18.2$ & $112.8 \pm 12.6$ & $233.5 \pm 15.3$ \\
\hline Centella asiatica & gotukola & $255.5 \pm 22.1$ & $980.2 \pm 53.2$ & $102.9 \pm 11.3$ & $255.6 \pm 9.4$ \\
\hline
\end{tabular}

$n=4$. DW, dry weight.

with occasional stirring, and salt $(1 \mathrm{~g})$ was added at the same time. This preparation is locally called "malluma."

Preparation of green leaves with coconut oil. Same samples mentioned above were used. Cooking of vegetables $(400 \mathrm{~g})$ involved frying for 5-10 $\mathrm{min}$ in an uncovered frying pan in boiling coconut oil $(100 \mathrm{~mL})$ with occasional stirring. Salt ( $1 \mathrm{~g})$ was added. This is locally called "stir-fried" preparation of green leaves.

Determination of bioaccessibility of lutein in vitro. Prior to digestion, cooked leafy vegetables were homgenized into pieces similar in size to chewed particles and subjected to an in vitro digestion procedure according to Chandrika et al. (15) that simulated the human gastrointestinal digestion. Briefly, about $5 \mathrm{~g}$ of the sample was weighed and put into a screw-capped flask containing $5 \mathrm{~mL}$ of distilled water and $1 \%(\mathrm{w} / \mathrm{v})$ ascorbic acid. The gastric phase $(\mathrm{pH} 2)$ was simulated by adding $5 \mathrm{~mL}$ of pepsin solution to the sample and $\mathrm{pH}$ adjusted with $2 \mathrm{M}$ $\mathrm{HCl}$. The solution was incubated in an orbital shaking water bath at $37^{\circ} \mathrm{C}$ for $1 \mathrm{~h}$. In the subsequent intestinal phase the $\mathrm{pH}$ was increased from 2 to 7.5 and a mixture of pancreatin and bile extract was added. The sample was incubated in a shaking water bath for $30 \mathrm{~min}$. After centrifugation the carotenoids released from the food matrix and appearing in the supernatant were extracted with organic solvents. The in vitro bioaccessible lutein was quantified with the RP-HPLC-DAD method described above.

Statistical analysis. Statistical analysis was carried out in Microsoft Excel. All the results were presented as mean \pm SD, $p$-values of less than 0.05 were considered to be significant.

\section{Results and Discussion}

Major pigments in GLVs used in the present study consist of xanthophylls, chlorophylls and carotenes. A total of eight different major peaks were noted in the 13 vegetables. A range of carotenoids was observed in the
GLVs but for each vegetable, only four main carotenoids were observed as usual. Though the HPLC chromatogram of all GLVs found to be similar with four main carotenoids, namely neoxanthin, violaxanthin, lutein and $\beta$-carotene, the major difference appeared to be their concentrations as shown in Fig. 1 for four types of vegetables.

Lutein and $\beta$-carotene were common carotenoids present in all leafy vegetables at measurable levels. These carotenoids are of importance in human health (17). The leafy vegetable species studied were rich in $\beta$ carotene and lutein as shown in Table 1. $\beta$-Carotene has a high pro-vitamin A activity whereas lutein is essential in reducing risk of cancer and macular degeneration. I. batatas was the richest source of $\beta$-carotene $(743.9 \pm 35.0 \mu \mathrm{g} / \mathrm{g}$ dry weight $(\mathrm{DW}))$ while $S$. angustatum showed the highest amount of lutein $(1,728.2 \pm$ $168.3 \mu \mathrm{g} / \mathrm{g}$ DW). The highest concentrations of both neoxanthin and violaxanthin were found in $C$. maxima (327.8 $\pm 13.7 \mu \mathrm{g} / \mathrm{g}$ DW and 818.5 $\pm 28.0 \mu \mathrm{g} / \mathrm{g} \mathrm{DW}$, respectively).

Lutein showed a wide variation in the concentration in cooked GLVs (Table 2), ranging from 288.5 \pm 35.6 to $1,235.3 \pm 70.4 \mu \mathrm{g} / \mathrm{g}$ DW. It was also evident that cooking caused a reduction in lutein levels (18) (Tables 1 and 2$)$ in stir-fried preparations $(p<0.001)$.

The percentage in vitro bioaccessibility of lutein in cooked GLVs varied from 10.1 to $72.9 \%$. It was significantly more than that of $\beta$-carotene (12 to $43 \%$ ) according to previous studies (15). This may be due to the fact that lutein is more hydrophilic than $\beta$-carotene.

\section{Conclusion}

This study shows that among the selected GLVs, less commonly consumed leaves, namely Polyscias scutellaria, Gymnema lactiferum, Syngonium angustatum, Boerhavia diffusa, Cucurbita maxima, Ipomoea batatas and Sesbania grandiflora contain higher lutein content when 
Table 2. Influence of heat processing on the bioaccessibility of lutein from test vegetables.

\begin{tabular}{|c|c|c|c|c|}
\hline \multirow[b]{2}{*}{$\begin{array}{c}\text { Cooked leafy } \\
\text { vegetable }\end{array}$} & \multirow[b]{2}{*}{$\begin{array}{l}\text { Traditional } \\
\text { preparations }\end{array}$} & \multicolumn{3}{|c|}{ Lutein in traditionally cooked vegetable $(\mu \mathrm{g} / \mathrm{g} \mathrm{DW})^{\mathrm{a}}$} \\
\hline & & $\begin{array}{c}\text { Total } \\
(\mu \mathrm{g} / \mathrm{g} \mathrm{DW}) \\
\text { Mean } \pm \mathrm{SD}^{\mathrm{b}}\end{array}$ & $\begin{array}{l}\text { In vitro accessible } \\
(\mu \mathrm{g} / \mathrm{g} \mathrm{DW}) \\
\text { Mean } \pm \mathrm{SD}^{\mathrm{b}}\end{array}$ & $\begin{array}{c}\text { In vitro } \\
(\%)\end{array}$ \\
\hline \multirow[t]{2}{*}{ Cucurbita maxima } & Malluma & $835.3 \pm 35.8$ & $300.7 \pm 31.4$ & 35.9 \\
\hline & Stir fried & $956.8 \pm 60.2$ & $459.8 \pm 34.6$ & 48.0 \\
\hline \multirow[t]{2}{*}{ Ipomoea batatas } & Malluma & $903.6 \pm 40.2$ & $300.5 \pm 18.5$ & 33.2 \\
\hline & Stir fried & $980.0 \pm 50.5$ & $450.6 \pm 40.5$ & 45.9 \\
\hline \multirow[t]{2}{*}{ Sesbania grandiflora } & Malluma & $338.5 \pm 30.6$ & $56.2 \pm 10.6$ & 16.6 \\
\hline & Stir fried & $833.5 \pm 46.4$ & $359.0 \pm 25.4$ & 43.0 \\
\hline \multirow[t]{2}{*}{ Centella asiatica } & Malluma & $288.5 \pm 35.6$ & $55.5 \pm 9.8$ & 19 \\
\hline & Stir fired & $305.5 \pm 36.5$ & $31.3 \pm 6.3$ & 10.1 \\
\hline \multirow[t]{2}{*}{ Manihot esculenta } & Malluma & $975.6 \pm 40.9$ & $580.5 \pm 9.3$ & 59.5 \\
\hline & Stir fired & $1,097.5 \pm 62.4$ & $800.8 \pm 15.6$ & 72.9 \\
\hline \multirow[t]{2}{*}{ Polyscias scutellaria } & Malluma & $302.3 \pm 14.5$ & $125.5 \pm 8.4$ & 41.5 \\
\hline & Stir fried & $505.6 \pm 20.3$ & $200.6 \pm 10.4$ & 39.6 \\
\hline \multirow[t]{2}{*}{ Gymnema lactiferum } & Malluma & $400.5 \pm 16.3$ & $137.8 \pm 8.4$ & 34.4 \\
\hline & Stir fired & $505.5 \pm 22.6$ & $258.9 \pm 14.6$ & 51.2 \\
\hline \multirow[t]{2}{*}{ Syngonium angustatum } & Malluma & $965.5 \pm 38.9$ & $376.9 \pm 23.5$ & 39.0 \\
\hline & Stir fired & $1,035.7 \pm 48.9$ & $450.4 \pm 20.8$ & 43.5 \\
\hline \multirow[t]{2}{*}{ Boerhavia diffusa } & Malluma & $855.3 \pm 56.7$ & $238.4 \pm 12.2$ & 27.8 \\
\hline & Stir fired & $1,235.3 \pm 70.4$ & $594.3 \pm 23.5$ & 48 \\
\hline \multirow[t]{2}{*}{ Triathema monogyna } & Malluma & $392.6 \pm 20.4$ & $56.4 \pm 4.5$ & 14.4 \\
\hline & Stir fried & $485.8 \pm 37.8$ & $98.2 \pm 7.5$ & 20.2 \\
\hline \multirow[t]{2}{*}{ Spinaces oleracea } & Malluma & $243.8 \pm 15.4$ & $106.2 \pm 10.4$ & 43.7 \\
\hline & Stir fired & $320.2 \pm 13.2$ & $154.2 \pm 25.7$ & 48.1 \\
\hline \multirow{2}{*}{ Amaranthus caudatus } & Malluma & $138.4 \pm 18.0$ & $85.6 \pm 34.5$ & 61.8 \\
\hline & Stir fried & $280.7 \pm 12.6$ & $143.5 \pm 50.3$ & 51.1 \\
\hline \multirow[t]{2}{*}{ Alternathera sessilis } & Malluma & $100.7 \pm 11.8$ & $50.2 \pm 13.4$ & 50.2 \\
\hline & Stir fried & $125.8 \pm 13.6$ & $60.3 \pm 14.5$ & 48.2 \\
\hline
\end{tabular}

${ }^{\text {a }}$ Dry matter one gram (g) includes vegetable and coconut oil or scraped coconut solid (fat, protein, etc.).

${ }^{\mathrm{b}}$ Mean \pm SD of all samples ( $n=5$ for total content, $n=5$ for in vitro content).

compared to that of commonly consumed GLVs. Percentage in vitro bioaccessibility of lutein from cooked GLVs is also considerably high in traditional preparations. Hence these GLVs could be exploited as a rich source of $\beta$-carotene and lutein to overcome vitamin A deficiency and AMD. These data on the composition of carotenoids could be used in intervention programs to improve the quality of life of the population in Sri Lanka as well as other developing countries.

\section{Acknowledgments}

This research was supported by the National Research Council Grant 2005: No. 05-36 and International Foundation for Science (Research grant No: E/ 3655-1).

\section{REFERENCES}

1) Seddon JM, Ajani UA, Sperduto FLD, Hiller R, Blair N, Burton TC, Farber MD, Gragoudas ES, Haller J, Miller DT. 1994. Dietary carotenoids, vitamins A, C, and E and advanced age-related macular degeneration. JAMA 272: 1413-1420.

2) Van het hof KH, Brower LA, West CE, Haddenan E, Steegers-Theunissen RPM, Von Düsseldorf M, Weststrate JA, Eskers TKAB, Haut vast JGAJ. 1999. Bioavail- ability of lutein from vegetables is 5 times higher than that of $\beta$-carotene. Am J Clin Nutr 70: 261-268.

3) Khachik F, Spangler CJ, Smith JC. 1997. Identification, quantification and relative concentrations of carotenoids and their metabolites in human milk and serum. Anal Chem 69: 1873-1881.

4) Sommerburg O, Kenuen JE, Bird AC, Van kuijk FJ. 1998. Fruits and vegetables that are sources for lutein and zeaxanthin: the macular pigment in human eyes. $\mathrm{Br} \mathrm{J}$ Ophthalmol 82: 907-910.

5) Mares-Perlman JA, Fisher AI, Palta M, Block G, Millen AE, Wright JD. 2001. Lutein and zeaxanthin in the diet and serum and their relation to age-related maculopathy in the third national health and nutrition examination survey. Am J Epidemiol 153: 424-432.

6) Curran-Celentano J, Hammond BR Jr, Ciulla TA, Cooper DA, Pratt LM, Danis RB. 2001. Relation between dietary intake, serum concentrations, and retinal concentrations of lutein and zeaxanthin in adults in a Midwest population. Am J Clin Nutr 74: 796-802.

7) Brown L, Rimm EB, Seddon JM, Giovannucci EL, Chasan-Taber L, Spiegelman D, Willett WC, Hankinson SE. 1999. A prospective study of carotenoid intake and risk of cataract extraction in US men. Am J Clin Nutr $\mathbf{7 0 :}$ 517-524.

8) Chasan-Taber L, Willett WC, Seddon JM, Stampfer MJ, Rosner B, Colditz GA, Speizer FE, Hankinson SE. 1999. 
A prospective study of carotenoid and vitamin A intakes and risk of cataract extraction in US women. Am J Clin Nutr 70: 509-516.

9) Gale CR, Hall NF, Phillips DI, Martyn CN. 2001. Plasma antioxidant vitamins and carotenoids and age-related cataract. Ophthalmology 108: 1992-1998.

10) Johnson EJ, Hammond BR, Yeum KJ, Qin J, Wang XD, Castaneda C, Snodderly DM, Rusell RM. 2000. Relation among serum and tissue concentrations of lutein and zeaxanthin and macular pigment density. Am J Clin Nutr 71: 1555-1562.

11) Landrum JT, Chen Y, Bone RA, Dixon Z, Micah S. 2000. Serum and macular pigment response to $2.4 \mathrm{mg}$ dosage of lutein. ARVO 41: S60.

12) Olmedilla B, Granado F, Bilanco I, Vaquero M. 2003. Lutein, but not alpha-tocopherol, supplementation improves visual function in patients with age-related cataracts: a 2-year double-blind, placebo-controlled pilot study. Nutrition 19: 21-24.

13) Dwyer JH, Navab M, Dwyer KM, Hassan K, Sun P, Shircore A, Hamalevy S, Hough G, Wang X, Drake T, Merx CN, Fogelman AM. 2001. Oxygenated carotenoid lutein and progression of early atherosclerosis. The Los Angeles Atherosclerosis study. Circulation 103: 29222927.

14) Mares-Perlman JA, Millen AE, Ficek TL, Hankinson SE. 2002. The body of evidence to support a protective role for lutein and zeaxanthin in delaying chronic disease. Overview J Nutr 132: 518S-524S.

15) Chandrika UG, Svanberg U, Jansz ER. 2006. Content and in vitro accessibility of beta-carotene from cooked Sri Lanka green leafy vegetable and their estimated contribution to vitamin A requirement. J Sci Food Agric 86: 54-61.

16) Rodriguez-Amaya DB. 1999. A Guide to Carotenoid Analysis in Foods. ILSI Press, Washington DC.

17) Su Q, Rowley KG, Itsiopoulos C, O'dea K. 2002. Identification and quantification of major carotenoids in selected components of the Mediterranean diet: green leafy vegetables, figs and olive oil. Eur J Clin Nutr 56: 1149-1154.

18) Padmavati K, Udipi Sa Rao M. 1992. Effect of different cooking methods on $\beta$-carotene content of vegetables. J Food Sci Technol 29: 137-140. 